\title{
BUSINESS AND LAW VOCABULARY ACQUISITION IN THE ESP CLASSROOM
}

\author{
Zuzana Hrdličková \\ University of Economics in Bratislava, Slovakia \\ zuzana.hrdlickova@euba.sk
}

\begin{abstract}
Undergraduates of the University of Economics in Bratislava need to receive decent economic and legal education to be able to work successfully in different areas of the national economy and in the management structures of all levels. The previous research has shown that Slovakia follows a significant negative trend with performance in reading. Online learning platforms like LMS Moodle are ideal for students in higher education. This paper is a part of the KEGA Project carried out at the Department of English Language of the Faculty of Applied Languages. It demonstrates the work of an experimental group of sixty-four first- and secondyear students of the Faculty of National Economy in a course "Business English for Advanced Students III" supported by an e-course "Business Communication". During the semester, students developed reading skills and improved communication by reading and investigating written discourse for unknown words and idiomatic expressions. The rationale for the quantitative research is to compose a corpus of professional articles from English-language periodicals read by "Economics and Law" students. The rationale for the qualitative research is to identify important business, legal and academic vocabulary in them. The method of "Statistical Hypothesis Testing", T-test, tests the significance of the difference between the knowledge of idioms of the experimental group and the control group (33 students doing a traditional course). The results indicate that LMS Moodle increased students' motivation to study English. The results prove that "Economics and Law" students enlarged greatly their legal vocabulary and that both groups were interested in learning idiomatic expressions.
\end{abstract}

Keywords: reading text; term; idiom; business; economics; law; technology.

\section{Introduction}

Unsatisfactory results achieved by the Slovak readers in the PISA 2003, 2006, 2009, 2012, 2015 and 2018 assessments and a negative trend with performance in reading provided the main impetus for investigating the linguistic features of general English reading texts in detail. Numerous research studies have concerned with the difficulties in processing reading texts by foreign language learners. Linguistic variables that contribute to the text being harder to process are syntactic complexity, lexical complexity, topic unfamiliarity, difficult vocabulary, high occurrence of idiomatic expressions, and homonyms. Research shows that conventionalised multiword expressions and the lexis itself have been neglected in language studies. This neglect can be ascribed to the vocabulary being viewed as the non-generative component.

Transitioning from being a successful secondary school student to being a successful university student can be difficult. Undergraduates have to adjust to different learning cultures and to accept that university study is different. The Department of English Language runs courses in English for Specific Purposes. Whether the students have acquired B1 or B2 English language levels in secondary school, in accordance with the CEFR (2011), they are mixed together and take two or three courses in "Business English for Advanced Students". During the semesters, they use a compulsory textbook Market Leader Business English Course Book (Cotton, Falvey \& Kent, 2011). A typical unit consists of the following sections: Starting up, Vocabulary, Reading, Listening, Language review, Skills, and a Case study. Reading sections include articles from The Financial Times, Bloomberg Businessweek, The Telegraph, The Sunday Times, CBS, and The Corporate Knights. Due to journalism, the reading texts are full of idiomatic expressions. At the end of each semester, students have to demonstrate the acquired knowledge via common departmental testing. Even though they are intelligent, they face difficulties in passing written examinations. Based on the disappointing results, reading literacy in English must also be developed in higher education.

Undergraduates need to study texts written by academics or experts with many years of teaching experience to gain knowledge independently from their field of study. They should distinguish at least between academic and journalistic styles and use the right vocabulary within their genres. According to Lea, Bull, Webb and Duncan (2014), academic vocabulary is divided into three broad categories. First, there is ordinary general English vocabulary that includes all the function words - articles, prepositions, conjunctions, as well as common verbs, adjectives and nouns for everyday things. At the other extreme, there is specialist subject vocabulary. This differs between different academic disciplines and can be highly technical. Typically, students need to learn these words as part of their subject studies, whether or not they are also learners of English. In between these two extremes, there is so-called "sub-technical" or "general

Hrdličková, Z. (2020). Business and law vocabulary acquisition in the ESP classroom. Advanced Education, 14, 56-65.

https://doi.org/10.20535/2410-8286.197507 
academic" vocabulary. These words tend to be used in general English. However, the way they are used in academic writing is often rather different.

The first thing the student needs to know about a new "word", obviously, is what it means. For some words, this will be relatively easy, because they carry roughly the same meaning in most contexts (e.g. achieve). Other words have a number of different meanings. Many of them may be related to each other, but they are used in slightly different ways (e.g. capital). Yet other words have a quite specific meaning in a particular area of study, e.g. significant, which the student may know as a synonym of important, but which has a much more precise meaning in statistics.

Researchers agree that knowing a word involves much more than simply knowledge of meaning and form (McCarthy, 1990; Laufer, 1997). Nation (2013), for instance, identifies nine different types of vocabulary knowledge that are a part of knowing a word. If the student is to use a word correctly and effectively in his/her writing, he/she needs to know how it behaves in context and how it combines with other words. This includes knowing its grammar, grammatical structures and complementation patterns a word may take (Lea, Bull, Webb \& Duncan, 2014).

Firth (1957) asserted that "You shall know a word by the company it keeps." (p.11). For him, this keeping company, which he called "collocation", was part of the meaning of a word. O'Dell and McCarthy (2008) define "collocation" as a natural combination of two or more words; it refers to the way English words are closely associated with each other. In addition, it is a pair or group of lexemes or words that are often used together. According to Crystal (1992), the term "collocation" means the habitual cooccurrence of individual lexical items. The potential of items to collocate is called their "collocability".

Two fundamental principles are seen to govern the choice of vocabulary when producing written or spoken text: "the open-choice principle" governing the "ad hoc" lexical composition of phrases and sentences, and "the idiom principle" governing the use of ready-made multiword expressions, that is, conventionalised ways of saying (Fernando, 1996). Kvetko (2006) describes multiword expressions, namely collocations and idioms, and considers idioms as an important part of everyone's vocabulary. According to Gillet (2010), it is necessary to acquire idioms to succeed in international and multinational workplaces.

An "idiom" is a phrase whose meaning is difficult or sometimes impossible to guess by looking at the meanings of the individual words it contains. For example, the phrase "bread and butter" has a literal meaning, but it also has a common idiomatic meaning. Some idioms are imaginative expressions that draw a comparison with another area of activity, e.g. "cast one's net widely", "break the mould", etc. However, imaginative idioms are actually very rare in academic English. Most idioms used in academic writing or business correspondence are not vivid in this way. The idiomatic expressions, whether imaginative or not, have the potential of appearing in mature written discourse. Regarding business English and idiomatic vocabulary, Parizoska and Rajh (2017) have drawn attention to the fact that figurative expressions, including idioms, are an important research topic in ESP, especially in business English since business discourse abounds with figurative language. They discuss idiom variation in business English textbooks and focus on sports idioms that are used to talk about competition in business, e.g. "in the driving seat", "move the goalposts", "a level playing field", etc. According to them, the application of the cognitive linguistic approach to teaching figurative language in ESP could be extended to include idiom variation.

Maierová (2018) deals with idiomatic expressions used in marketing communication in English with a special focus on advertising. According to her, idioms are used in this discourse due to their attractiveness and memorability, e.g. "If you pay peanuts, you get monkeys.", "stand your ground", "The customer is always right.", "Just do it." etc. However, she states that idioms can present a certain problem for non-native speakers and thus she pays attention to the ways how learners of English can master them.

Spišiaková (2018) analyses economic texts in the journal "Altenativas Económicas". She focuses on the the use of loan words, especially anglicisms, metaphors, locutions and other phraseologisms, e.g. "la guinda del pastel", "estar a la cola", etc. She states that the current Spanish business language is full of metaphors and phraseologisms that previously occurred in spoken or literary styles. In business communication, it is a strategy how to cause readers or listeners to be more interested in the writing or speech of their counterparts.

Considering spoken communication, Thyab (2016) observed the professors of English and their use of idiomatic expressions in EFL/ESL classrooms. While native speakers used them very often, non-native speakers of English scarcely used them. She states that not only professors but also many non-native learners of English, especially those of Arabic origin, have problems with understanding and using idiomatic expressions adequately when communicating in English. In her view, it is natural that they find idioms difficult to understand because they do not know what the image the idiomatic expression is based on. She explains, for example, the images of "carrot and stick", "show one the ropes", "fight a losing battle" etc. Thyab also points out to the fact that many idioms are culture based. Native speakers use them on a daily 
basis as it is an essential part of their vocabulary. Thus, it is a necessity for non-native speakers of English to become aware and proficient in using English idiomatic expressions.

Ciprianová and Vrábelová (2015) tested 85 Slovak students' comprehension of nine English figurative idioms, e.g. "turn a blind eye to sth", "change hands", "set one's heart on sth" etc. The three body parts eye, hand and heart - are not equally productive metaphorical source domains in English and Slovak. Their research results indicate that different prominence of the source domains in students' mother tongue and the target language is one of the factors that influence idiom comprehension in a foreign language.

Nearly all of the above-mentioned idioms occur in business English textbooks. As for the first-year Slovak university students' written and spoken communication, it lacks the use of academic or business vocabulary and idiomatic expressions. Since the KEGA Project was aimed at developing reading literacy and improving communication, all the students became familiar with business terms and idioms through a textbook or newspaper and magazine articles. In addition, "Economics and Law" students enriched their vocabulary with "legal terms" - words/word combinations which stand for general names of legal concepts have specific and definite meanings and are often used in legislation and legal documents (Pigolkin and Chernobel, 1990).

As we know, lawyers or litigators, paralegals or legal researches, legal secretaries or trainee lawyers need to use legal English vocabulary in their work. English language learners may need to use legal English to work with foreign colleagues or clients, to describe or explain aspects of their own legal systems, or to find out about other systems. In the course "British, American and Slovak Studies", students of the Faculty of International Relations need to talk and write about legal systems of English-speaking countries. They are encouraged to think about how far our own system shares the same legal concepts or procedures and to decide whether to use a legal term in English as an equivalent to a concept in our own system or to employ an approximation in discussion or writing. Students of this faculty were also included in the KEGA Project in order to examine current phraseology in diplomacy (Rusiňáková, 2019).

Ignatkina (2018) states that the knowledge of legal terminology enables students to fit new information (e.g. linguistic, disciplinary, factual and cultural) into the framework of the legal system they are studying. The acquisition of terminology in a foreign language implies knowledge of both conceptual content and the means of its verbalisation. Her study argues for a cognitive approach to teaching legal English, and frame modelling as an effective method of teaching and learning legal terminology.

Mukhametzyanova, Bezuglova and Kuznetsova (2015) discuss specific features of teaching legal vocabulary in foreign language classes. They claim that linguistic university graduate should not only master the norms of written and spoken foreign language. To be competitive at labour market and be ready to modern conditions of globalisation, the graduate should master on a high level general English vocabulary as well as legal English vocabulary. They are interested in the terminology of law and based on the classification of branches of English law, they describe a required minimum of legal vocabulary. In addition, they discuss methods, forms, strategies and techniques of teaching and learning legal terms.

Students who wish to develop their knowledge of legal English vocabulary during their legal studies can use specialised reference books and dictionaries focused on law. These will also help extend the vocabulary of business professionals who need some knowledge of legal English vocabulary for commercial agreements and transactions (Brown \& Rice, 2007). Law (2015) puts emphasis on accessible language. He designed his dictionary to meet the needs of students following law courses at all levels and those who require clear explanations of legal concepts and terminology. Moreover, Mason (2011) points out to the importance of collocations, e.g. "to breach a contract", "a fatal error", "to accept liability", etc.

According to Kontanistova, Martynenko, Kovrigina and Kreuzova (2016), reading newspapers is important for more than the obvious reason of keeping up on local, national and international current events. Reading the newspaper can prepare the student for the legal business world. Reading a business-centred paper like "The Wall Street Journal" or the latest legal industry news on the lawyer.com as one of the leading websites for the entire legal professional can be beneficial. These authors recommend reading newspapers. Joyce (2003) believes that newspapers are a useful tool in the ELT classroom for improving reading skills and state that all learners should read the news. Donna (2000) and Taylor (2006) suggest practising skills such as understanding the news and reading business texts in order to develop and improve business skills.

The aim of the study is to find out whether reading newspaper and magazine articles and acquiring idiomatic expressions from them will contribute to the positive results achieved in an idiomatic test, to compose the corpus of professional articles read by all "Economics and Law" students, and to demonstrate how the corpus of each student was analysed.

The paper tests the significance of the difference between the knowledge of idioms of both groups via the hypotheses: Hypothesis $\mathrm{H}_{1}$ : Due to the alternative reading strategy, the students of the experimental 
group will enhance their knowledge of idioms. Considering business and legal vocabulary, Hypothesis $\mathrm{H}_{2}$ is as follows: If "Economics and Law" students read articles from one source focused on both business and law, they will compose the corpuses of important business and legal terms.

\section{Methods}

Participants. In order to confirm the effectiveness of teaching with the use of LMS Moodle, a pedagogical experiment was conducted at the University of Economics in Bratislava in the academic year 2018/2019. Five groups of first- and second-year students of the Faculty of National Economy (NHF) and the Faculty of Commerce (OF) were chosen for the experiment. The essence of the pedagogical experiment was as follows: Three groups of participants were included in the experimental group (all groups from NHF, one group was "Economics and Law" first-year students) and two groups of participants in the control group (NHF, OF). The experimental group consisted of 64 participants and the control group of 33 participants.

Materials and procedure. All the participants in the research were enrolled on a course "Business English for Advanced Students III". The control group did a traditional course in business English, i.e. the participants only used Market Leader Business English Course Book (Cotton, Falvey \& Kent, 2011). The experimental group also used a compulsory textbook, but this course was supported by an e-course "Business Communication" in LMS Moodle. By means of technology, participants in the experimental group developed their reading literacy in English and thus improved their communication. They read articles from online versions of English-language newspapers or magazines such as Forbes, The Guardian, The Economist, The Independent, Newsweek, MoneyWeek, New Law Journal, The Law Society Gazzette and many others.

During the semester, both groups dealt with four compulsory units - Raising money, Customer service, Crisis management, and Mergers and acquisitions (Cotton, Falvey \& Kent, 2011). However, each participant of the experimental group was supposed to work with 12 more articles from online sources. Since the main aim of the KEGA Project was to explore current idioms in use, first of all, the participants had to identify at least two idioms in each article, then, to highlight unknown words, to get the main idea of each article and, finally, to get ready for a mini-presentation of each article. Moreover, 21 "Economics and Law" students searched for legal terms, as well. To understand clearly the meaning of difficult vocabulary in each article, the participants used print or online versions of English-language dictionaries such as www.merriamwebster.com, idioms.thefreedictionary.com, en.oxforddictioanries.com, dictionary.cambridge.org, and the like. After submitting their work into LMS Moodle, they regularly received feedback on every article from the lecturer who confirmed the (in)correctness of their homework. To determine the correct economic concepts, legal concepts and idioms, the lecturer mainly consulted dictionaries such as Oxford Business English Dictionary for Learners of English (2005), Oxford Learner's Dictionary of Academic English (2014), Oxford Dictionary of Law (2015), and Cambridge Idioms Dictionary (2006). She also consulted publications by McCarthy and O'Dell (2016), Gillet (2010), Brown and Rice (2007), Cowie, Mackin and McCaig (1993), Kvetko (2014), and Hrdličková (2016, 2017, 2018).

Data analysis. At the end of the semester, both groups of participants sat for an idiomatic test. There were two variations; each of them consisting of 30 idioms. In order to analyse the achieved results, the method of "Statistical Hypothesis Testing" was used. An 'Independent Two-Sample T-test' tested the significance of the difference between the sample means (Kučerová \& Fidlerová, 2012).

\section{Results}

The paper aimed to define whether acquiring idiomatic expressions from articles will contribute to the positive results achieved in an idiomatic test. Participants of both the experimental and control groups sat for an idiomatic test consisting of 30 business English idioms. Table 1, Table 2 and Figure 1 show the grades (absolute and relative frequencies) achieved in an idiomatic test by the participants of the experimental and control groups and a graphic representation of the achieved grades.

Table 1. Grades achieved in an idiomatic test

\begin{tabular}{|l|c|c|c|c|c|c|}
\hline \multirow{2}{*}{ Group } & \multicolumn{7}{|c|}{ Grades (absolute frequencies) } \\
\hline--- & $1(\mathrm{~A})$ & $1,5(\mathrm{~B})$ & $2(\mathrm{C})$ & $2,5(\mathrm{D})$ & $3(\mathrm{E})$ & $4(\mathrm{FX})$ \\
\hline Experimental & 14 & 12 & 15 & 7 & 9 & 7 \\
\hline Control & 6 & 5 & 8 & 7 & 2 & 5 \\
\hline
\end{tabular}


Table 2. Grades achieved in an idiomatic test

\begin{tabular}{|l|c|c|c|c|c|c|}
\hline \multirow{2}{*}{ Group } & \multicolumn{6}{|c|}{ Grades (relative frequencies in \%) } \\
\hline--- & $1(\mathrm{~A})$ & $1,5(\mathrm{~B})$ & $2(\mathrm{C})$ & $2,5(\mathrm{D})$ & $3(\mathrm{E})$ & $4(\mathrm{FX})$ \\
\hline Experimental & $21,9 \%$ & $18,8 \%$ & $23,4 \%$ & $10,9 \%$ & $14,1 \%$ & $10,9 \%$ \\
\hline Control & $18,2 \%$ & $15,2 \%$ & $24,2 \%$ & $21,1 \%$ & $6,1 \%$ & $15,2 \%$ \\
\hline
\end{tabular}

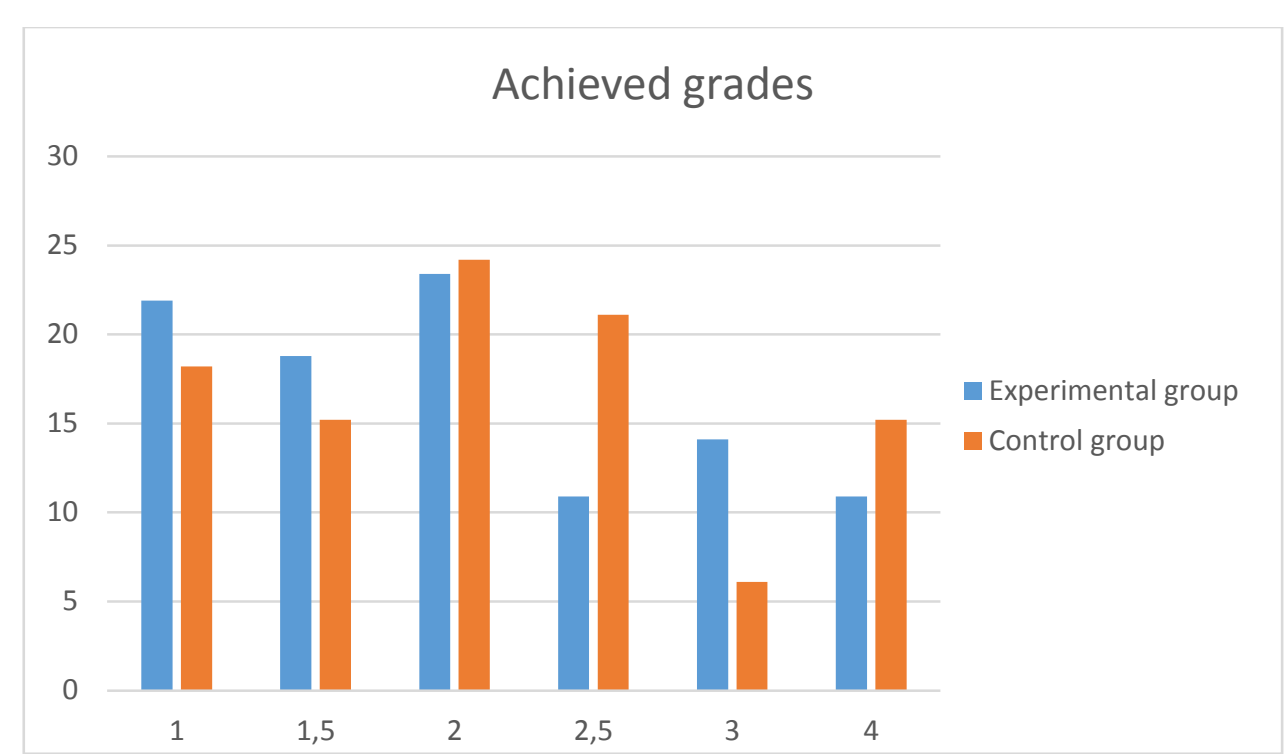

Figure 1. A graphic representation of the achieved grades.

Table 3 shows the finding: At the significance level of 5\% $(\alpha=0.05)$, the hypothesis $\mathrm{H}_{1}$ was rejected because the probability $\mathrm{p}>\alpha$, that is, the difference between the experimental and the control groups is not significant in the grades achieved in an idiomatic test.

Table 3. The difference between the experimental and control groups in an idiomatic test

\begin{tabular}{|l|r|r|}
\hline & Experimental group & Control group \\
\hline Expected value & 2,101563 & 2,212121 \\
\hline Variance & 0,874442 & 0,922348 \\
\hline Observation & 64 & 33 \\
\hline Covariance & 0,890579 & \\
\hline $\begin{array}{l}\text { Hypothetical difference of } \\
\text { expected values }\end{array}$ & 0 & \\
\hline Difference & 95 & \\
\hline test statistics & $-0,54666$ & \\
\hline $\mathbf{P}(\mathbf{T}<=\mathbf{t})(\mathbf{1})$ & 0,292947 & \\
\hline $\mathbf{t}$ crit (1) & 1,661052 & \\
\hline $\mathbf{P}(\mathbf{T}<=\mathbf{t})(\mathbf{2})$ & 0,585894 & \\
\hline $\mathbf{t}$ crit $\mathbf{( 2 )}$ & 1,985251 & \\
\hline
\end{tabular}

The results of the research can be satisfying, even though there was not a significant difference between the experimental and control groups. It can be compared with the results from the previous academic year 2017/2018 when the experimental group reached 70.0\% in an idiomatic test and the control group 55.0\%. Regarding the 21 "Economics and Law" students, they achieved 474 points out of 630 that equals $75.23 \%$. Reading newspaper and magazine articles and acquiring idiomatic expressions from them definitely contributed to the positive results achieved in an idiomatic test. 


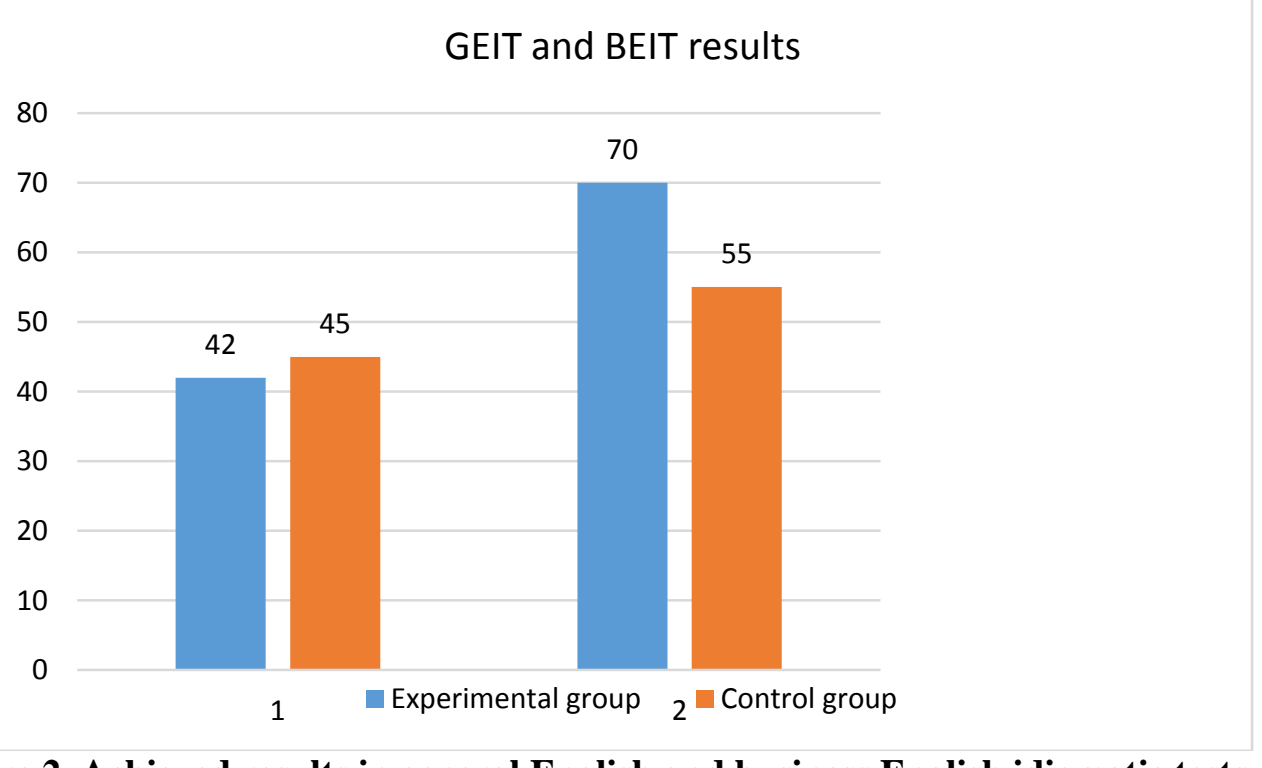

Figure 2. Achieved results in general English and business English idiomatic tests

After analysing the data it was found out that the following numbers of participants in the research decided themselves to read these newspapers and magazines: Forbes (6), The Guardian (6), MoneyWeek (3), The Economist (2), New Law Journal (2), The Independent (1), and The Law Society Gazette (1). As for the whole group of "Economics and Law" students, each of them submitted his/her work with 12 texts into LMS Moodle and received feedback from the lecturer on each one. Altogether, they read 252 articles and composed a 179,301-word corpus. The three out of twenty-one students who chose legal magazines read 37 articles about legal issues. The rest of the students read 32 articles about law, 12 articles about lawyers, and 9 articles about legal issues. Altogether, it was 90 articles focused on law.

Two corpuses of articles of "Economics and Law" Student 1 and Student 2 who reached 50.0\% and 96.6\% in an idiomatic test can be seen in Appendix 1.

New Law Journal is a weekly British legal magazine for legal professionals that provides information on case law, legislation and changes in practice. It is evident that the articles were shorter and Student 1 was interested in categories such as Legal aid focus, Legal services, Litigation trends, Child law, Training \& Education, Profession, etc. Text $\mathrm{A}$ and Text $\mathrm{J}$ were very interesting and informative.

Forbes is a bi-weekly American business magazine that features original articles on finance, industry, investing, and marketing topics. It also reports on related subjects such as technology, communications, science, politics, and law. Student 2 read longer articles that can be found in the categories like Leadership Text 1 (Careers), Texts 3, 4 (Entrepreneurs), Texts 6, 9 (ForbesWomen), Text 7 (Leadership Strategy), Texts 8, 12 (Education), Text 10 (Diversity \& Inclusion), Texts 2, 11 - Leadership, and Text 5 - Policy.

As it can be seen in the analysis of her texts, she had problems with vocabulary. She found out the meanings of individual words and identified parts of speech: noun (n), adjective (adj), verb (v), and adverb $(\mathrm{adv})$. In the first four texts, she was not able to identify any idiomatic expressions. In Texts $5-12$ she found idioms and some verbs or phrasal verbs were considered as idioms in some online dictionaries. The work of this student was excellent, especially with Text 1 , Text 8 and Text 9.

After submitting the work with each article into LMS Moodle, the student received feedback from the lecturer in the following way: a) underlined economic and business terms - business English vocabulary, b) words in bold - legal English vocabulary, c) words in bold italics - idioms, d) abbreviations - preposition (prep), phrasal verb (phr v), collocation (coll.), abbreviation (abbr.), especially (esp.), important terms from human resources - (HR) added to the vocabulary list, and e) focus on three categories - business, law and idioms. In the last category, the lecturer distinguished between academic English (AcadE), business English (BusE), and general English.

The following qualitative analysis serves as an example of how the students worked with difficult vocabulary, and it looks at the terms, collocations and idiomatic expressions that the lecturer recommends for the study (see Appendix 2).

Student 2 acquired 183 new words and had a possibility to enrich her vocabulary with 304 important business and legal concepts and idioms (see Appendix 3). Regarding business and legal vocabulary, Hypothesis $\mathrm{H}_{2}$ was confirmed. 


\section{Discussion}

A low quality of first-year university students' written and spoken discourse has been observed for more than ten years. The quality of business English seminars has continuously been increased by implementing LMS Moodle into the teaching-learning process. As it can be seen, the work of the experimental group of students was quite ambitious. In agreement with Nimrita (2016), we can state that LMS Moodle is an appropriate supportive environment for the independent nature of learning in higher education.

The articles under investigation focused on business and legal issues were first used effectively by the students, and then by the lecturer. The aim of a quantitative analysis was to compose of corpus of professional texts. A qualitative analysis revealed the students' preferences and dealt with difficult and idiomatic vocabulary. The analysis also shows how each student of the experimental group (64) worked with reading assignments and received feedback from the lecturer.

The knowledge of idioms of both groups was tested and compared via "Statistical Hypothesis Testing", T-test. Even though there was not a significant difference between the knowledge of idioms of the two groups, it can be stated that both groups achieved better results this semester than in the previous one as well as much better results in an end-of-term test from business English.

We also agree with Maierová (2018), Ciprianová and Vrábelová (2015), Parizoska and Rajh (2017), and Thyab (2016), that idioms cause problems for non-native speakers of English and are an important research topic in ESP, especially in business English. In general, students liked using LMS Moodle and working with articles. There is a need to stress that apart from developing reading literacy, students also developed cultural, intercultural, information and media literacies. Looking for idioms in English-language articles, whether in class or at home, can be a good alternative of making seminars more appealing to university students. Moreover, "Economics and Law" students can widen their vocabulary with legal terms.

Research revealed that business English is full of idiomatic expressions. In academic English, idioms function as adjuncts, conjuncts or disjuncts, e.g. "in due course", "in order to do sth", "in one's view", "of course (not)", etc. and are frequently used. These idioms are important to acquire since they can make students' academic writing mature. Imaginative idioms occur mainly in business and general English (Hrdličková, Rusiňáková \& Maierová, 2019). Also, many terms such as "consumer", "client", "contract", "ownership", "reputation" etc. are important terms in business English as well as in legal English. Students of a joint bachelor's study programme "Economics and Law" - the students of both the Faculty of National Economy of the University of Economics in Bratislava - stated that it was very useful for them to connect the knowledge of business and law and to understand better both fields.

It is strongly recommended to study and investigate legal vocabulary within business English and to focus on important legal vocabulary as Mason (2011) and Mukhametzyanova, Bezuglova and Kuznetsova (2015) suggest. Of course, there might be some limitations as not all lecturers are keen on using technology, however, there is no population more technologically skilful than post-secondary students and the virtual landscape of LMS Moodle is the one they can navigate through easily.

\section{Conclusions}

Undergraduates of the University prepare themselves for the work in enterprises, banking and other financial institutions, in central bodies of state administration as well as in national, international or multinational companies. Professional articles enabled them to improve their reading skills and to learn essential business, legal, academic and idiomatic vocabulary. Most students had no idea of what the term "idiom" was at the beginning and it took them a long time to find some. Thanks to the lecturer's help, they finally gathered many idiomatic expressions. This paper proves that students were interested in learning idioms. However, it is important to distinguish among idioms that can be used in business English, academic English or general English. If they use some of them from time to time and in the appropriate context, they will sound more native-like.

In a questionnaire focused on students' opinion on implementing LMS Moodle into the teachinglearning process, students were very grateful for the challenging work and the lecturer's feedback. We strongly recommend using technology and doing various activities with students. This project is a clear proof of increased quality of the process that helped them make academic progress.

To conclude, LMS Moodle proved to be a very useful learning platform in "Business Communication" e-course. Therefore, it is more than convenient to create e-courses in "Academic Writing" or "Legal English" to support the traditional ones. From the results of the previous research into idiomatic expressions, within the KEGA Project, it can be stated that there are many differences between formal, neutral and informal vocabulary in English. University students need to acquire academic and legal vocabulary and thus further 
research will be focused on expressions that are frequent in academic and legal contexts and which may present problems of choosing between formal, neutral and less formal alternatives.

\section{Acknowledgements}

This paper is part of the Project KEGA 015EU-4/2017 Idioms in Business Communication (Idiomatické výrazy v obchodnej komunikácii), subsidised by the Ministry of Education, Science, Research and Sport of the Slovak Republic.

\section{References:}

Brown, G.D., \& Rice, S. (2007). Professional English in Use Law. Cambridge: Cambridge University Press.

Ciprianová, E. \& Vrábelová, M. (2015). Slovak students' comprehension of English figurative idioms containing body parts. Topics in Linguistics, 15(1). https://doi.org/10.2478/topling-2015-0003

Cowie, A.P., Mackin, R., \& McCaig, I.R. (1993). Oxford Dictionary of English Idioms. Oxford: Oxford University Press.

Crystal, D. (1992). An Encyclopedic Dictionary of Language and Languages. Oxford: Blackwell Publishers.

Cotton, D., Falvey, D., \& Kent, S. (2011). Market Leader Business English Course Book Upper Intermediate (3rd ed.). Harlow: Pearson Education Limited.

Donna, S. (2000). Teach Business English. Cambridge: Cambridge University Press.

Firth, J.R. (1957). A synopsis of linguistic theory 1930-1955. Studies in linguistic analysis (pp.1-32). Oxford: Blackwell.

Fernando, C. (1996). Idioms and Idiomaticity. Oxford: Oxford University Press.

Gillet, A. (2010). Speak Business English Like an American. Ann Arbor, MI: Language Success Press.

Hrdličková, Z. (2016). Ideational Idioms in Business English Communication. Bratislava, SK: Vydavatel'stvo EKONÓM.

Hrdličková, Z. (2017). Business English Idioms vs. Business Terms. Lingua et Vita, 6(12), 22-29. Retrieved from https://linguaetvita.sk/

Hrdličková, Z. (2018). Promoting Media, Information and Reading Literacy through a Business Communication e-Course. In Beseda, J., \& Rohlíková, L. (Eds.), DisCo 2018: Overcoming the Challenges and the Barriers in Open Education: 13th conference reader (pp.178-198). Prague, CZ: Centre for Higher Education Studies.

Hrdličková, Z. (2018). Improving Reading Skills Using On-line Newspapers and Magazines. Lingua et Vita, 7(14), 75-84. Retrieved from https://linguaetvita.sk/

Hrdličková, Z., Rusiňáková, J., \& Maierová, E. (2019). Economic Concepts and Idioms in English Business Communication. České Budějovice, CZ: College of European and Regional Studies, z.ú.

Ignatkina, A. (2018). Frame modelling method in teaching and learning legal terminology. Studies in logic, grammar and rhetoric, 53(66), 81-104. https://doi.org/10.2478/slgr-2018-0005

Joyce, K. (2003). Newspapers are a useful tool in the ELT classroom for improving reading skills and enhancing students' knowledge of current affairs. British Council. Retrieved from http://www.teachingenglish.org.uk/article/newspaper-reading-activities

Kontanistova, A., Martynenko, I., Kovrigina, O., \& Kreuzova, V. (2016). Legal English for Master's Programme. Moscow: Kutafin Moscow State Law University.

Kučerová, M., \& Fidlerová, H. (2012). Štatistické metódy. Bratislava, SK: Slovak University of Technology.

Kvetko, P. (2006). An Outline of English Phraseology (2nd ed.). Trnava, SK: University of Ss Cyril and Methodius in Trnava.

Kvetko, P. (2014). Anglicko-slovenský frazeologický slovník [English-Slovak Dictionary of Phraseology]. Bratislava, SK: Veda.

Laufer, B. (1997). What is in a word that makes it hard or easy? Intralexical factors affecting the difficulty of vocabulary acquisition. In N.Schmitt, \& M.McCarthy (Eds.), Vocabulary: Description, acquisition and pedagogy (pp.140-155). NY: Cambridge University Press.

Law, J. (Ed.). (2015). Oxford Dictionary of Law (2nd ed.). Oxford: Oxford University Press.

Lea, D., Bull, V., Webb, S., \& Duncan, R. (Eds.). (2014). Oxford Learner's Dictionary of Academic English. Oxford University Press.

Maierová, E. (2018). Idioms in Marketing Communication. Lingua et Vita, 7(14), 24-30. Retrieved from https://linguaetvita.sk

Mason, C. (2011). The Lawyer 's English Language Coursebook (2nd ed.). Birtley, ENG: Global Legal English Ltd.

McCarthy, M. (1990). Vocabulary. Oxford: Oxford University Press.

McCarthy, M., \& O'Dell, F. (2016). Academic Vocabulary in Use (2nd ed.). Cambridge: Cambridge University Press.

Mukhametzyanova, L.R., Bezuglova, O.A., \& Kuznetsova, A.A. (2015). Specific features of teaching legal vocabulary in foreign language classes. Journal of Language and Literature, 6(2), 117-122. https://doi.org/10.7813/j11.2015/6-2/23

Nation, I.S.P. (2013). Learning vocabulary in another language. Cambridge: Cambridge Applied Linguistics.

Nimrita, P. (2016, March). 5 Ways Moodle Improves Higher Education. Lambda Solutions. Retrieved from https://blog.lambdasolutions.net/5-ways-moodle-improves-higher-education

O’Dell, F., \& McCarthy, M. (2008). English Collocations in Use Advanced. Cambridge: Cambridge University Press.

Parizoska, J., \& Rajh, I. (2017). Idiom Variation in Business English Textbooks: A Corpus-Based Study. ESP Today, 5(10), 46-67. https://doi.org/10.18485/esptoday.2017.5.1.3

Parkinson, D., \& Noble, J. (Eds.). (2005). Oxford Business English Dictionary for Learners of English. Oxford: Oxford University Press.

Pigolkin, A.S. \& Chernobel, G.T. (1990). Legal terminology: definition and classification. In A.S. Pigolkin (Ed.), Language of law (pp.62-69). Moscow.

Rusiňáková, J. (2018). English Idioms - Theory and Practice. Lingua et Vita, 7(14), 48-54. Retrieved from https://linguaetvita.sk/ Spišiaková, M. (2018). Contemporary Spanish Business Language. Lingua et Vita, 7(13), 42-54. Retrieved from https://linguaetvita.sk/ Taylor, K. (2006). Fifty ways to improve your Business English ... without too much effort! London: Summertown Publishing.

Thyab, R.A. (2016). The Necessity of Idiomatic Expressions to English Language Learners. International Journal of English and Literature, 7(7), 106-111. https://doi.org/10.5897/IJEL2016.0895

Using the CEFR: Principles of Good Practice. (2011, October). Cambridge: UCLES EMC/7571/1Y09.

Walter, E. (Ed.). (2006). Cambridge Idioms Dictionary (2nd ed.). Cambridge: Cambridge University Press.

Walter, E. (Ed.). (2006). Cambridge Phrasal Verbs Dictionary (2nd ed.). Cambridge: Cambridge University Press. 
Appendix 1

Student 1 - New Law Journal articles

\begin{tabular}{|l|l|r|}
\hline Text & Headline & Word count \\
\hline Text A & Frozen out of justice & 1,388 \\
\hline Text B & Tackling the £1,3bn dishonesty market & 315 \\
Text C & No deal: a good deal for criminals? & 353 \\
\hline Text D & Unduly lenient scheme marks three decades & 255 \\
\hline Text E & Building justice Clydeside & 246 \\
\hline Text F & Crime gang siblings convicted of £1m money laundering & 133 \\
\hline Text G & London: holding its own? & 957 \\
\hline Text H & All change as Brexit rolls on & 288 \\
\hline Text I & Toppling the four pillar & 979 \\
\hline Text J & Your background is an asset - make the most of it & 882 \\
\hline Text K & Sentencing Council issues mental health guidelines for judges & 319 \\
\hline Text L & Student contributions recognised & 168 \\
\hline Text M & Children left without experts & 322 \\
\hline--- & Total & $\mathbf{6 , 6 0 5}$ \\
\hline
\end{tabular}

Student 2 - Forbes articles

\begin{tabular}{|l|l|r|}
\hline Text & Headline & Word count \\
\hline Text 1 & I Fought The Law and The Law Won: My Burnout Story & 980 \\
\hline Text 2 & How To Score Your Law Firm Local Media Coverage & 947 \\
\hline Text 3 & How To Raise Money & 1,335 \\
\hline Text 4 & An Institute For Law And Innovation & 1,277 \\
\hline Text 5 & What More Can The Law Do For Women? & 1,119 \\
\hline Text 6 & How Customer Service Helps Small Fish Swim With The Sharks & 719 \\
\hline Text 7 & Nike: A Real-Time Lesson In Crisis Management & 781 \\
\hline Text 8 & Why The Rich And Famous Would Break The Law To Get Their Kids Into College & 729 \\
\hline Text 9 & Advice For Young Women: Don't Let Fear Prevent You From Starting Your Own Business & 1,231 \\
\hline Text 10 & How To Overcome A Toxic Leader: Lessons From Southern Poverty Law & 727 \\
\hline Text 11 & How HR Is Key To Successful Mergers And Acquisitions & 630 \\
\hline Text 12 & \#Metoo And The Right To Legal Representation Clash At Harvard Law School & 961 \\
\hline-- & Total & $\mathbf{1 1 , 4 3 6}$ \\
\hline
\end{tabular}

\section{Appendix 2}

Text 1: Davis-Laack, P. (2018, May 17). I Fought The Law and The Law Won: My Burnout Story. Forbes. Retrieved from https://www.forbes.com/

STUDENT: burn out (phr v), prompt (adj), exceedingly (adv), thud (n), pick up (v), bug (v), rub (v), outwardly (adv), forgetfulness $(\mathrm{n})$, resurrect (v), misnomer (n), dread (v), attribute (v), indicate (v)

LECTURER'S FEEDBACK: 1) Business - assessment, burnout, deal (Commerce), poor performance (coll.), turnover (HR); 2) Law - client, law, real estate; 3) Idioms used in:

a) Academic English - as a result (of sth) (also coll. in AcadE), in more/further, etc. detail, on your/its own, take sb/sth seriously, b) Business English - ---,

c) General English - burst into tears, keep a secret, make progress, on top of one's game/at the top of one's game, rub sb the wrong way $(A m E) /$ rub sb up the wrong way $(B r E$, AustrE)

Text 8: Horn, M. (2019, March 27). Why The Reach And Famous Would Break The Law To Get Their Kids Into College. Forbes. Retrieved from https://www.forbes.com/

STUDENT: in the wake of (AcadE), scam (n), allegedly (adv), fraud (n), bribery (n), aghast (adj), shed (v), mogul (n), myopia (n), brazenly (adv), framework (n), underlying (adj), affirmation, candor (n), reinvent (v), buck (n), descend (v), muck (n); IDIOMS: get into, break the law, for sth's sake (AcadE), leg up, slip down

LECTURER'S FEEDBACK: 1) Business - colleague, conduct an interview (coll.), conduct research (coll.), conduct a survey (coll.), finding, a large fortune (coll.), private equity (n) (Finance); 2) Law-the rule of law (also in AcadE; 3) Idioms used in:

a) Academic English - all but, be all about sb/sth, beside the point, cast/shed/throw light on sth, deep down rather infml, a number of $\mathrm{sb} / \mathrm{sth}$

b) Business English - in business

c) General English - give sb a leg up infml, take a/the/this/that/another/such a step

Text 9: Barratt, B. (2019, March 27). Advice For Young Women: Don’t Let Fear Prevent You From Starting Your Own Business. Forbes. Retrieved from https://www.forbes.com/

STUDENT: plot (v), canvass (v), disparity (n), livelihood (n), attest (v), self-esteem (n), like-minded (adj), abandonment (n), attempt (n), knock (n), perception (n), consciously (adv), oppressive (adj), overcome hurdle (coll.), perceive (v), persistent (adj); IDIOMS: come down, grow up, start out, look up to, get sb down, put/give one's mind to sth, set one's mind (on/to sth/to doing sth)

LECTURER'S FEEDBACK: 1) Business - consultancy, costs, de-motivator, employer, empower, entrepreneurship, founder, fund (v) (Finance), get a job (coll.), grow one's business (coll. in AcadE), motivate, network, networking, order, run a business (also coll. in AcadE), start a business (coll.), start-up, steep learning curve (coll.), win respect (also coll. in AcadE); 2) Law - ---; 3) Idioms used in:

a) Academic English - as a whole, even if, in particular, this/that is not to say (that)

b) Business English - take a (hard/severe, etc.) knock infml 
c) General English - at play, a hell of a infml, lose money, the odds are (stacked) against sb/(doing) sth, take sth as it comes, take steps (to do sth) (also coll. in AcadE)

Appendix 3

Business, Legal and Idiomatic vocabulary

\begin{tabular}{|c|c|c|c|c|}
\hline Text & Student 2 & $\begin{array}{l}\text { Lecturer's feedback } \\
\text { (Business Terms) }\end{array}$ & $\begin{array}{c}\text { Lecturer's feedback } \\
\text { (Legal Terms) }\end{array}$ & $\begin{array}{c}\text { Lecturer's feedback } \\
\text { (Idioms) }\end{array}$ \\
\hline Text 1 & $14(3$ BusE) & 5 & 3 & 9 \\
\hline Text 2 & $14(6$ BusE, 1 Law $)$ & 9 & 3 & 10 \\
\hline Text 3 & 13 (6 BusE, 1 Idiom $)$ & 13 & 0 & 18 \\
\hline Text 4 & $11(5$ BusE) & 7 & 5 & 4 \\
\hline Text 5 & $15(4 \mathrm{BusE})$ & 2 & 17 & 3 \\
\hline Text 6 & 13 (4 BusE, 2 Idioms) & 30 & 3 & 5 \\
\hline Text 7 & 11 (3 BusE, 1 Idioms) & 14 & 0 & 10 \\
\hline Text 8 & 23 (2 BusE, 3 Idioms, 2 Law) & 7 & 1 & 9 \\
\hline Text 9 & 23 (4 BusE, 2 Idioms) & 19 & 0 & 11 \\
\hline Text 10 & $18(1$ BusE, 1 Law $)$ & 23 & 2 & 4 \\
\hline Text 11 & 13 (4 BusE, 1 Idiom $)$ & 25 & 1 & 6 \\
\hline Text 12 & $15(3$ BusE) & 1 & 18 & 7 \\
\hline Total & 183 & 155 & 53 & 96 \\
\hline
\end{tabular}

